\title{
Humic Acid-Induced Hairy Root Growth in Basil Ismodulated by Nitric Oxide and Reactive Oxygen Species
}

\author{
Flávio Couto Cordeiro ${ }^{1 *}$, Claudete Santa-Catarina², Vanildo Silveira ${ }^{3}$, \\ Roberta Cristiane Ribeiro ${ }^{4,5}$, Sonia Regina de Souza ${ }^{1}$
}

\author{
${ }^{1}$ Plant Biochemistry Laboratory (LBP), Department of Chemistry, Federal Rural University of Rio de Janeiro (UFRRJ), Seropédica, \\ Brazil \\ ${ }^{2}$ Cell Biology and Tissue Laboratory (LBCT), Center for Bioscience and Biotechnology (CBB), State University of Norte \\ Fluminense Darcy Ribeiro (UENF), Campos dos Goytacazes, Brazil \\ ${ }^{3}$ Biotechnology Laboratory (LBT), Center for Bioscience and Biotechnology (CBB), State University of Norte Fluminense Darcy \\ Ribeiro (UENF), Campos dos Goytacazes, Brazil \\ ${ }^{4}$ Plant Nutrition Laboratory (LNP), Department of Soils, Federal Rural University of Rio de Janeiro (UFRRJ), Seropédica, Brazil \\ ${ }^{5}$ Instituto Federal de Educação, Ciência and Tecnologia of Mato Grosso (IFMT), Sorriso, Brazil \\ Email: *fcordeiro@ufrrj.br
}

How to cite this paper: Cordeiro, F.C., Santa-Catarina, C., Silveira, V., Ribeiro, R.C. and de Souza, S.R. (2017) Humic Acid-Induced Hairy Root Growth in Basil Ismodulated by Nitric Oxide and Reactive Oxygen Species. American Journal of Plant Sciences, 8, 3140-3161.

https://doi.org/10.4236/ajps.2017.812212

Received: October 18, 2017

Accepted: November 24, 2017

Published: November 27, 2017

Copyright (c) 2017 by authors and Scientific Research Publishing Inc. This work is licensed under the Creative Commons Attribution International License (CC BY 4.0).

http://creativecommons.org/licenses/by/4.0/ (c) (i) Open Access

\begin{abstract}
The bioactivity of humic acids (HA) is mainly due to the presence of auxin analogs. In turn, nitric oxide (NO) production in plants affects root growth and may result from endogenous auxin production or the application of synthetic auxin analogs or HA. Nitric oxide signaling may be related to the bioactivity of the HA. Although the auxin, NO, and ROS-mediated activity of HA has been studied, no studies exist on their effects in Ocimum basilicum L., commonly known as basil. A study under controlled in vitro conditions was performed using hairy roots (hairy roots) of basil grown in medium with $\mathrm{N}$ $\mathrm{NO}_{3}^{-}(0.5$ or $5.0 \mathrm{mM})$ and subjected to treatments with $\mathrm{HA}\left(3 \mathrm{mMC} \cdot \mathrm{L}^{-1}\right)$ or sodium nitroprusside (SNP; $100 \mu \mathrm{M}$ ), an NO donor, either without or with 2-(4-carboxyphenyl)-4,4,5,5-tetramethylimidazoline-1-oxyl-3-oxide (cPTIO; $200 \mu \mathrm{M})$, an NO scavenger. The addition of HA and SNP resulted in significant increases in the root growth, associated with increased $\mathrm{NO}$ and reactive oxygen species (ROS) contents. The application of the NO scavenger cPTIO with the SNP and HA decreased the effects of both substances on the root growth and endogenous levels of the NO and ROS. The increased root growth promoted by the NO donor (SNP) and HA was also associated with increased proton pump and catalase activity for both $\mathrm{N}^{-\mathrm{NO}_{3}^{-}}$levels tested. The results showed that the effects of HA are dependent on NO and ROS, which act as messengers, inducing root growth.
\end{abstract}




\section{Keywords}

$\mathrm{H}^{+}$-ATPases, Auxins, Humic Acid, Ocimum basilicum L., Root Growth

\section{Introduction}

Plant adaptation and survival under adverse conditions may be directly related to the ability of roots to respond to several factors, such as water, light, and nutrient availability. Regarding plant adaptation and survival, roots may adapt to adverse conditions due to their high plasticity, being able to induce the initiation of root primordia, resulting in the emission of lateral roots to better explore the available environmental resources [1].

Nitrogen (N) is widely recognized as being an essential element for plant growth [2]. In agricultural and aerobic soils, nitrate $\left(\mathrm{NO}_{3}^{-}\right)$is the main $\mathrm{N}$ source and plays a crucial role in root growth [3]. Its uptake by roots depends on specific plasma membrane transporters, enzyme activity for $\mathrm{N}$ reduction and assimilation, and energy availability for both processes [4].

The cellular and molecular bases of the action of humic acids (HA) in plant $\mathrm{NO}_{3}^{-}$uptake are not fully understood. However, studies indicate that HA stimulate the activity and promote the synthesis of plasma membrane $\mathrm{H}^{+}$-ATPases, having similar effects to auxin, a plant hormone that acts on the different pathways involved in plant development [5] [6]. Humic acids, together with humins and fulvic acids, compose the humic substances (HS), which constitute the largest part of soil organic matter [7]. Studies have confirmed the association of HS with exogenous auxins, with both present in the environment, resulting in lateral root induction [8].

The increased emission of absorbent hairs and lateral roots in response to HA is usually related to interactions among $\mathrm{HA}$, auxin, and nitric oxide (NO) [9] [10] [11]. Nitric oxide plays a central role in the determination of the root morphology and developmental pattern [11] [12] [13]. [14] used an NO scavenger to prevent the formation of lateral and adventitious roots and root gravitropic response, indicating an important role of endogenous NO in mediating these processes.

Reactive oxygen species (ROS) production is traditionally considered part of the oxidative burst under conditions detrimental to plants [15]. However, evidence exists of specific roles of ROS in plant growth regulation and cellular signaling [16] and root growth [17]. Nitric oxide has been observed to be involved in HA-induced lateral root development and proton pump activation in corn roots [5].

Several research groups currently study this subject, and although studies have investigated the auxin-, NO-, and ROS-mediated activity of HA, no studies have specifically focused on Ocimum basilicum L., commonly known as basil. In addition, the results reported concerning interactions among these compounds are 
controversial [9] [10] [11] [17] [18] [19]. Due to its diversified chemical profile and chemical relevance, $O$. basilicum L. has been widely used in both the pharmaceutical and the food and cosmetic industries [20].

The aim of the present study was to clarify the role of HA in root growth, proton pump and catalase activity, and NO and ROS biosynthesis using the transformed basil (Ocimum basilicum L.) roots in a closed system in vitro.

\section{Materials and Methods}

\subsection{Hairy Root}

Transgenic basil roots produced by [21] (in press) were used. Basil explants originating from in vitro cultures were infected with laboratory-produced Agrobacterium rhizogenes strain R1601, containing gene npt II under the control of the CaMV 35S promoter, obtained from the Federal University of Viçosa.

\subsection{Extraction and Composition of Humic Acid (HA)}

Humic substances (HA) were extracted as described by the International Humic Substance Society [22], isolated from haplic histosols (located in Pinheiral, Rio de Janeiro-Brazil), collected at $0.00-0.20 \mathrm{~m}$ depth. In brief, 10 volumes of $0.5 \mathrm{M}$ $\mathrm{NaOH}$ was mixed with one volume of soil under an $\mathrm{N}_{2}$ atmosphere. After $12 \mathrm{~h}$, the suspension was centrifuged at 5,000 $\mathrm{xg}$ and acidified to $\mathrm{pH} 1.5$ using $6 \mathrm{M} \mathrm{HCl}$.

Solubilization and precipitation of the HA were repeated three times, and the last pellet was mixed with 10 volumes of a diluted mixture of $\mathrm{HF}-\mathrm{HCl}$ solution (5 $\mathrm{mL} \cdot \mathrm{L}^{-1} \mathrm{HCl} 12 \mathrm{M}+5 \mathrm{~mL} \cdot \mathrm{L}^{-1} \mathrm{HF} 48 \%$, v/v). After centrifugation (5,000 $\mathrm{xg}$ ) for 15 min, the sample was repeatedly washed with water until a negative test against $\mathrm{AgNO}_{3}$ was obtained, followed by dialysis against deionized water using a 12 - 14 $\mathrm{kDa}$ cutoff membrane (Thomas Scientific, Swedesboro, NJ, USA). The dialyzate was lyophilized and characterized chemically, and the HA powder was solubilized with 50 to $100 \mathrm{~mL}$ of $0.05 \mathrm{M} \mathrm{NaOH}$, with the final $\mathrm{pH}$ being adjusted to 5.5 with $0.1 \mathrm{M} \mathrm{HCl}$.

The elemental composition was determined using a CHN Perkin-Elmer Auto analyzer (Perkin-Elmer, Foster City, CA, USA). Total acidity $\left(\mathrm{Ba}(\mathrm{OH})_{2}\right.$ method) and carboxylic acidity $\left(\mathrm{Ca}(\mathrm{OAc})_{2}\right.$ method) were determined, followed by potentiometric titration. The E4/E6 ratios were determined by dissolving $1 \mathrm{mg}$ of $\mathrm{HA}$ in $5 \mathrm{~mL}$ of $0.05 \mathrm{M} \mathrm{NaHCO}_{3}$, with the final $\mathrm{pH}$ being adjusted to 8.3 with $\mathrm{NaOH}$. The absorbances at $465 \mathrm{~nm}$ and $665 \mathrm{~nm}$ were measured on a Shimadzu spectrophotometer (Shimadzu, Kyoto, Japan). The ratio between these absorbances corresponded to the E4/E6.

\subsection{Plant Growth and Treatments}

Thirty-five days after transplanting (DAT), the solution was changed, and the hairy roots were placed in modified minimal medium (MM) without $\mathrm{N}-\mathrm{NO}_{3}^{-}$ for $72 \mathrm{~h}$ to deplete the $\mathrm{N}$ inside the cells. Uniform $3-\mathrm{cm}$ segments of hairy roots were then transferred to Erlenmeyer flasks containing half-strength modified 
$\mathrm{MM}$, with low $(0.5 \mathrm{mM})$ or high $(5 \mathrm{mM}) \mathrm{N}-\mathrm{NO}_{3}$ level; this medium was supplemented with HA (3 mMC) or sodium nitroprusside (SNP), an NO donor, both without or with 2-(4-Carboxyphenyl)-4,4,5,5-tetramethylimidazoline-1-oxyl-3oxide (CPTIO; $200 \mu \mathrm{M}$ ), an NO scavenger.

Following treatment application, the roots were incubated for 5 days under stirring at $90 \mathrm{rpm}$ in the dark. After 5 days of incubation, root samples from the different treatments were collected and used to determine the root growth and nitrate reductase (NR), glutamine synthetase (GS), and catalase activity. $\mathrm{N}$ metabolism was evaluated by quantifying soluble fractions $\left(\mathrm{N}-\mathrm{NO}_{3}^{-}, \mathrm{N}-\mathrm{NH}_{4}^{+}\right.$, free amino-N, and soluble sugars), proton pump activity, and NO and ROS endogenous production.

The roots were weighed for fresh weight, and a separate aliquot of $0.50 \mathrm{~g}$ was used for the evaluation of catalase activity, which is expressed in moles of $\mathrm{H}_{2} \mathrm{O}_{2}$ (hydrogen peroxide) per min per $\mathrm{mg}^{-1}$ protein ${ }^{-1}$, and total protein, which is expressed as $\mathrm{mg}$ of protein $\mathrm{g}^{-1}$ fresh weight. The dry weight of the roots, which were dried in a forced circulation oven at $65^{\circ} \mathrm{C}$, was also assessed. To measure the lateral root density, seedlings ( 10 replicates in two independent experiments) were harvested after 7 days of treatment, and the number of lateral roots (LRs) per seedling and the length of the primary root were measured. The density of the LRs along the primary root was calculated by dividing the number of LRs by the primary root length and is expressed as the number of LRs per $\mathrm{cm}$.

\subsection{N Metabolism}

Shoot and root samples ( $1 \mathrm{~g}$ fresh mass-FM) from the different treatments were homogenized in $80 \%$ ethanol. After a chloroform partition had been performed (Fernandes, 1984), the $\mathrm{N}-\mathrm{NO}_{3}^{-}$[23], free amino-N [24], and $\mathrm{N}-\mathrm{NH}_{4}^{+}$[25] contents were determined in the resulting soluble fractions.

\subsection{Determination of Soluble Sugars}

Soluble sugars [26] were determined in $0.2-\mathrm{mL}$ aliquots of alcoholic extract by colorimetry in specific reaction medium. The reaction medium was prepared by dilutinganthrone $(0.4 \mathrm{~g})$ in sulfuric acid: distilled water $(5: 2)$, where it was allowed to stand for approximately 45 minutes before being used. The tubes were cooled, and the absorbance of the reaction product was determined at $620 \mathrm{~nm}$ and compared with a glucose standard.

\subsection{Nitrate Reductase (NR) Activity, Glutamine Synthetase (GS) Activity, and Catalase Activity}

NR activity was determined according to the methodology in [27]. Samples of root tissue (200 $\mathrm{mg} \mathrm{FM}$ ) were incubated in the dark in $5 \mathrm{~mL}$ of phosphate buffer $0.1 \mathrm{M} \mathrm{pH} \mathrm{7.5,} \mathrm{containing} \mathrm{n-propanol} \mathrm{at} 2 \%$ and $0.02 \mathrm{M}$ of $\mathrm{KNO}_{3}$, at $30^{\circ} \mathrm{C}$ in a double-boiler for $60 \mathrm{~min}$. After the incubation, $0.4-\mathrm{mL}$ aliquots were extracted from the incubation solution of each sample and stored; then, $0.3 \mathrm{~mL}$ of $1 \%$ sulfanilamide $(\mathrm{m} / \mathrm{v})$ and $0.3 \mathrm{~mL}$ of $0.02 \%(\mathrm{~m} / \mathrm{v}) \mathrm{n}$-naphthyl-ethylene-diamine were 
added to these aliquots, followed by incubation for 20 min. After incubation, 4 $\mathrm{mL}$ of distilled water was added to the aliquots. Absorbance was measured with a spectrophotometer at $540 \mathrm{~nm}$, and the concentration of $\mathrm{NO}_{2}^{-}$was determined using a standard $\mathrm{NO}_{2}^{-}$curve. In the calculation of the activity of this enzyme, it was used quantities of $\mathrm{NO}_{2}^{-}$in reaction medium.

GS activity was determined according to the methodology described by [28]. Samples of root tissue ( $1 \mathrm{~g}$ FM) were macerated in liquid $\mathrm{N}_{2}$. Next, $8 \mathrm{~mL}$ of imidazole- $\mathrm{HCl}$ buffer $\mathrm{pH} 7.5,0.1 \mathrm{M} \mathrm{MgSO}_{4}$, and mercaptoethanol were used to homogenize the samples. Then, the homogenized samples were strained through gauze, and the filtered samples were stored in centrifuge tubes immersed in an ice bath. Afterwards, the samples were centrifuged at 15,000 xg for $15 \mathrm{~min}$ at $0^{\circ} \mathrm{C}$, and the supernatant was collected and stored on ice.

For the reaction, $0.2 \mathrm{~mL}$ of $0.5 \mathrm{M}$ imidazole- $\mathrm{HCl}$ buffer $\mathrm{pH} 7.5,0.1 \mathrm{~mL}$ of 0.1 $\mathrm{M}$ mercaptoethanol, $0.1 \mathrm{~mL}$ of $0.4 \mathrm{M} \mathrm{MgSO}_{4}, 1 \mathrm{~mL}$ of $0.1 \mathrm{M}$ hydroxylamine $\mathrm{pH}$ $6.5,0.1 \mathrm{~mL}$ of $0.1 \mathrm{M}$ ATP, $0.1 \mathrm{~mL}$ of $0.5 \mathrm{M}$ glutamate $\mathrm{pH} 7.5,0.3 \mathrm{~g}$ of sample, and $1.0 \mathrm{~mL}$ of distilled water were added. Afterwards, the samples were incubated at $30^{\circ} \mathrm{C}$ for $30 \mathrm{~min}$. Next, the reaction was interrupted by the addition of $1.5 \mathrm{~mL}$ of a solution consisting of iron chloride and trichloroacetic acid dissolved in $0.5 \mathrm{M} \mathrm{HCl}$. The absorbance of the samples was measured at $540 \mathrm{~nm}$ using $\gamma$-glutamylmonohydroxamate as a standard. GS activity was expressed in $\mathrm{m}$ moles of $\gamma$-glutamylmonohydroxamate produced per minute per gram of FM.

Catalase activity was determined according the methodology described by [29]. Samples of hairy roots (200 $\mathrm{mg}$ FM) from the different treatments were macerated with liquid $\mathrm{N}_{2}$. A total of $2 \mathrm{~mL}$ of extraction solution, consisting of 0.1 $\mathrm{m}$ MEDTA in $0.1 \mathrm{M}$ potassium phosphate buffer ( $\mathrm{pH} 6.8$ ) and containing $0.2 \%$ $\mathrm{m} / \mathrm{v}$ of PVPP (polyvinylpolypyrrolidone), was added, and the samples were re-homogenized at $4^{\circ} \mathrm{C}$. The homogenized material was centrifuged at 12,000 $\mathrm{xg}$ for 15 minutes at $4^{\circ} \mathrm{C}$, and the supernatant was used for enzyme evaluations and protein quantification. Catalase activity was determined by adding $100 \mu \mathrm{L}$ of crude enzyme extract to $900 \mu \mathrm{L}$ of reaction medium that consisted of $12.5 \mathrm{mM}$ $\mathrm{H}_{2} \mathrm{O}_{2}$ in $50 \mathrm{mM}$ potassium phosphate buffer $(\mathrm{pH} 7.0)$ at $30^{\circ} \mathrm{C}$. Enzyme activity was determined by the decrease in absorbance at $240 \mathrm{~nm}$ in the 2 -min interval after the beginning of the reaction; this absorbance was compared to the $\mathrm{H}_{2} \mathrm{O}_{2}$ standard. The calculation of the enzymatic activity was based on [30] using the molar extinction coefficient of $36 \mathrm{M}^{-1} \cdot \mathrm{cm}^{-1}$.

\subsection{Proton Pump Activities}

The isolation of plasmalemma and tonoplast vesicles was performed according to the methodologies proposed by [31], with some modifications.

Root samples ( $5 \mathrm{~g} \mathrm{FM}$ ) were macerated at $4^{\circ} \mathrm{C}$ with 10 to $20 \mathrm{~mL}$ of the extraction medium containing the following: $50 \mathrm{mM}$ Tris- $\mathrm{HCl}(\mathrm{pH} 8.0), 250 \mathrm{mM}$ sucrose, $100 \mathrm{~mL} \cdot \mathrm{L}^{-1}$ glycerol, $150 \mathrm{mM}$ potassium iodide (KI), $100 \mathrm{mM}$ choline chloride, $2 \mathrm{mM}$ ethylene glycol tetraacetic acid (EGTA), $2 \mathrm{mM}$ ethylenediami- 
netetraacetic acid (EDTA), $10 \mathrm{~g} \cdot \mathrm{L}^{-1}$ polyvinylpolypyrrolidone (PVP), $1 \mathrm{mM}$ phenylmethylsulfonyl fluoride (PMSF), $5 \mathrm{mM}$ dithiothreitol (DTT), $5 \mathrm{mM}$ 2-mercaptoethanol, and $5 \mathrm{~g} \cdot \mathrm{L}^{-1}$ of albumin. The homogenate was filtered with four layers of gauze and then centrifuged at 3,600 $\mathrm{xg}$ for $10 \mathrm{~min}$ at $4^{\circ} \mathrm{C}$. The supernatant was collected and centrifuged again at $8,000 \mathrm{xg}$ for $10 \mathrm{~min}$. The supernatant was recollected and recentrifuged at 105,000 $\mathrm{g}$ for $40 \mathrm{~min}$. The resulting supernatant was discarded, and the precipitate was resuspended with $2 \mathrm{~mL}$ of a medium containing $30 \mathrm{mM}$ Tris- $\mathrm{HCl}(\mathrm{pH} 7.5), 150 \mathrm{~mL} \cdot \mathrm{L}^{-1}$ glycerol, $1 \mathrm{mM}$ EGTA, $1 \mathrm{mM}$ EDTA, $2 \mathrm{mM} \mathrm{MgCl}$, $2 \mathrm{mM}$ DTT, and $1 \mathrm{mM}$ PMSF. The resulting sample was then placed on a sucrose gradient of $430 \mathrm{~g} \cdot \mathrm{L}^{-1} / 300 \mathrm{~g} \cdot \mathrm{L}^{-1} / 100 \mathrm{~g} \cdot \mathrm{L}^{-1}$ and centrifuged at 105,000 $\mathrm{xg}$ for $2 \mathrm{~h}$ at $4^{\circ} \mathrm{C}$. The plasmalemma and tonoplast vesicles were separated by flotation density, forming bands that could be collected and diluted in suspension medium in a 2:1 proportion (medium:band). These separate fractions were subjected to a 105,000 $\mathrm{xg}$ centrifugation for $40 \mathrm{~min}$ at $4^{\circ} \mathrm{C}$. The supernatant was discarded, and the precipitate was resuspended in 1 $\mathrm{mL}$ of suspension medium. Proteins were frozen in liquid $\mathrm{N}_{2}$ and stored at $-25^{\circ} \mathrm{C}$ for subsequent analysis. The protein concentration was determined according to [32], using bovine serum albumin as a standard.

The activity of the proton pumps plasmatic membrane $\mathrm{P}-\mathrm{H}^{+}$-ATPases, $\mathrm{V}-\mathrm{H}^{+}$-ATPases and $\mathrm{H}^{+}$-PPases was determined by the quantification of inorganic phosphate ( $\mathrm{Pi}$ ) liberated by ATP ( $\mathrm{P}$ and $\mathrm{V}-\mathrm{H}^{+}$-ATPase) and PPi ( $\mathrm{H}^{+}$-PPase) hydrolysis. The reaction medium for the $\mathrm{P}-\mathrm{H}^{+}$-ATPase consisted of $30 \mathrm{mM}$ MOPS-BTP (pH 6.5), $5 \mathrm{mM} \mathrm{MgSO}_{4}, 50 \mathrm{mMKCl} 50,1 \mathrm{mM} \mathrm{Na}{ }_{2} \mathrm{MoO}_{4}, 0.2 \mathrm{~mL} \cdot \mathrm{L}^{-1}$ of Triton X-100, $50 \mathrm{mM} \mathrm{KNO}_{3}, 1 \mathrm{mM} \mathrm{NaN}_{3}$, and $5 \mathrm{mM} \mathrm{ATP}$. The reaction medium for the $\mathrm{V}-\mathrm{H}^{+}$-ATPases consisted of $30 \mathrm{mM}$ HEPES-BTP ( $\mathrm{pH}$ 7.5), $5 \mathrm{mM}$ $\mathrm{MgSO}_{4}, 50 \mathrm{mM} \mathrm{KCl}, 1 \mathrm{mM} \mathrm{Na}_{2} \mathrm{MoO}_{4}, 0.2 \mathrm{mM}$ Triton X-100, $0.2 \mathrm{mM} \mathrm{Na}_{3} \mathrm{VO}_{4}, 1$ $\mathrm{mM} \mathrm{NaN}_{3}$, and $5 \mathrm{mM} \mathrm{ATP}$. The reaction medium for $\mathrm{H}^{+}$-PPase consisted of 30 mM HEPES-BTP (pH 7.2), $5 \mathrm{mM} \mathrm{MgSO}_{4}, 100 \mathrm{mMKCl}, 0.2 \mathrm{~mL} \cdot \mathrm{L}^{-1}$ of Triton $\mathrm{X}-100,1 \mathrm{mM} \mathrm{NaN}$, and $1 \mathrm{mM} \mathrm{PPi}$. For all proton pumps, the reaction was started by adding $4 \mu \mathrm{g}$ protein $/ \mathrm{mL}$ of medium. After $30 \mathrm{~min}$ at $30^{\circ} \mathrm{C}$, the reaction was stopped by adding $0.5 \mathrm{~mL}$ of the abovementioned reaction medium plus $1 \mathrm{~mL}$ of stop medium containing $20 \mathrm{~mL} \cdot \mathrm{L}^{-1} \mathrm{H}_{2} \mathrm{SO}_{4}, 50 \mathrm{~g} \cdot \mathrm{L}^{-1} \mathrm{SDS}$, and $7 \mathrm{~g} \cdot \mathrm{L}^{-1}$ $\left(\mathrm{NH}_{4}\right)_{2} \mathrm{MoO}_{4}$, which had been previously stored in an ice bath $\left(4^{\circ} \mathrm{C}\right)$. Then, 50 $\mu \mathrm{L}$ of $100 \mathrm{~g} \cdot \mathrm{L}^{-1}$ ascorbic acid was added. After $10 \mathrm{~min}, 1.45 \mathrm{~mL}$ of medium containing $40 \mathrm{~g} \cdot \mathrm{L}^{-1}$ of sodium citrate and $20 \mathrm{~g} \cdot \mathrm{L}^{-1}$ of glacial acetic acid was added to prevent the measurement of phosphate $(\mathrm{Pi})$ released by the residual activity of $\mathrm{H}^{+}$-ATPases and acid hydrolysis of ATP. The color was completely developed after $30 \mathrm{~min}$, and the spectrophotometric reading was carried out at $820 \mathrm{~nm}$.

\subsection{NO and Oxygen-Reactive Species (ROS) Production}

To visualize NO and ROS production in vivo, segments of root apices were isolated and placed in 12-well culture plates (four segments/well) that contained different treatments with HA ( $3 \mathrm{mM}$ carbon) and SNP $(100 \mu \mathrm{M})$, either com- 
bined or not with cPTIO $(200 \mu \mathrm{M})$, in $0.1 \mathrm{mM}$ HEPES-KOH buffer. After 5 days of incubation, the endogenous production of $\mathrm{NO}$ and ROS in these different treatments was evaluated.

For NO, the samples of the transformed basil roots were treated with $10 \mu \mathrm{M}$ of the fluorescent probe 4,5-diaminofluorescein diacetate (DAF-FM-DA; Calbiochem), which is an NO probe permeable to the plasma membrane, according to the description by [33]. The samples remained incubated in the different HEPES-KOH buffer treatments for $2 \mathrm{~h}$ at $25^{\circ} \mathrm{C}$, agitated at $90 \mathrm{rpm}$ in the dark. Negative control was conducted by incubating the roots with the NO scavenger cPTIO (2-(4-carboxyphenyl)-4, 4, 5, 5-tetramethylimidazoline-1-oxyl-3-oxide) (Sigma-Aldrich) and with no labeling probe. Next, the roots were washed three times with the respective incubation medium, and slides were prepared for their visualization with an Axioplan fluorescence microscope (Carl Zeiss, Jena, Germany), which was adapted with a digital camera (AxioCam MRc5) and AxioVisionLE software v4.8 (Carl Zeiss, Jena, Germany). The following filters were used for the DAF-FM-DA probe: an excitation wavelength at $495 \mathrm{~nm}$ and an emission wavelength at $515 \mathrm{~nm}$. The fluorescence intensity of the individual root apices was determined using the AxioVisionLE software v4.8 (Carl Zeiss, Jena, Germany), and the data are presented as the number of pixels per area $\left(\mu \mathrm{m}^{2}\right)$.

ROS analyses were performed according to [33]. Samples of the transformed basil roots were treated with $15 \mu \mathrm{M}$ of the fluorescent probe 2', 7 '-dichlorodihydrofluorescein diacetate $\left(\mathrm{H}_{2} \mathrm{DCFDA}\right.$; Calbiochem), an indicator of the ROS permeable to the plasma membrane. The $\mathrm{H}_{2}$ DCFDA was dissolved in DMSO to a final concentration of $0.1 \%(\mathrm{v} / \mathrm{v})$. The samples were incubated in their respective treatments in HEPES-KOH buffer for $2 \mathrm{~h}$ at $25^{\circ} \mathrm{C}$ and agitated at $90 \mathrm{rpm}$ in the dark. The hairy roots without labeling probe were incubated as a negative control. At the end of the 2-h incubation, the roots were washed three times with their respective incubation media, and slides were prepared for their visualization in an Axioplan fluorescence microscope (Carl Zeiss, Jena, Germany), adapted with a digital camera (AxioCam MRc5) and AxioVisionLE software v4.8 (Carl Zeiss, Jena, Germany). For the $\mathrm{H}_{2} \mathrm{DCFDA}$ probe, the following filters were used: excitation wavelength at $495 \mathrm{~nm}$ and emission at $515 \mathrm{~nm}$. The fluorescence intensity of the root apices was determined using the AxioVisionLE software v4.8 (Carl Zeiss, Jena, Germany), and the data are presented as the number of pixels per area $\left(\mu \mathrm{m}^{2}\right)$.

\subsection{Statistical Analysis}

The data were analyzed by performing an ANOVA and the Scott-Knot test to determine the differences between treatments and controls $(\mathrm{P}<0.05$ was considered statistically significant).

\section{Results}

The growth rates of the hairy roots of basil increased $210 \%$ and $180 \%$ for the HA 
treatment and $200 \%$ and $150 \%$ for the SNP treatment with 0.5 and $5.0 \mathrm{mM} \mathrm{N}$ $\mathrm{NO}_{3}^{-}$, respectively (Figure 1). Increases in root size were observed for both the treatments with $\mathrm{HA}$ and SNP, even when tested with the lower $\mathrm{N}-\mathrm{NO}_{3}^{-}$supply, indicating that the association of NO donor may activate a cascade of biochemical events related to cell growth, culminating in the induction of root morphogenesis.

At high $\mathrm{N}-\mathrm{NO}_{3}^{-}$concentrations, the treatments with $\mathrm{HA}$ and SNP had NR activity was higher for the Control and HA treatments (Figure 2(a)). By contrast, with $5.0 \mathrm{mM} \mathrm{N}-\mathrm{NO}_{3}^{-}$, the SNP treatment resulted in a decrease in NR activity with the high $\mathrm{N}-\mathrm{NO}_{3}^{-}$supply. This result may have been due to the $\mathrm{NR}$ inhibition at high $\mathrm{N}-\mathrm{NO}_{3}^{-}$concentrations in the presence of the $\mathrm{NO}$ donor. One of the pathways of the $\mathrm{NO}$ formation in plants is dependent on $\mathrm{NO}_{2}^{-}$formation
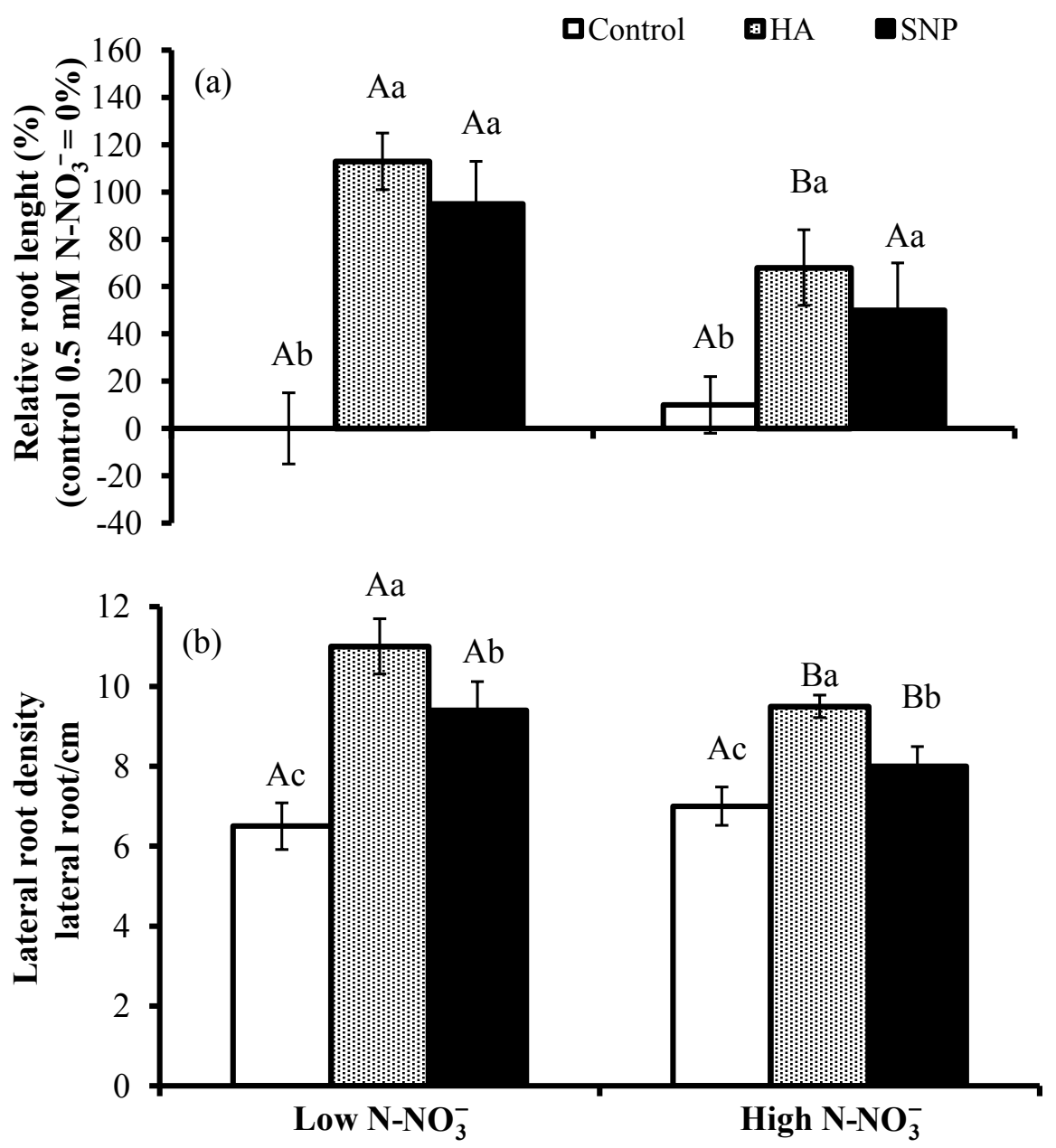

Figure 1. Relative root length (\%) (a) and lateral root density of transformed basil roots on the 5th day of incubation for the Control (without HA or SNP); treatment with HAhumic acid extracted from haplic histosols $\left(3 \mathrm{mM}\right.$ Carbon $\left.\mathrm{L}^{-1}\right)$; and treatment with SNPsodium nitroprusside, as an NO donor $(100 \mu \mathrm{M}$ SNP) applied in low $(0.5 \mathrm{mM})$ and high $(5.0 \mathrm{mM})$ doses of $\mathrm{N}-\mathrm{NO}_{3}^{-}$. The same uppercase letter between the $\mathrm{N}-\mathrm{NO}_{3}^{-}$doses and the same lowercase letter within the $\mathrm{N}^{-} \mathrm{NO}_{3}^{-}$doses do not differ among themselves according to the Scott-Knot test $(\mathrm{P} \leq 0.05)$. Vertical bars indicate standard error $(\mathrm{n}=4)$. 

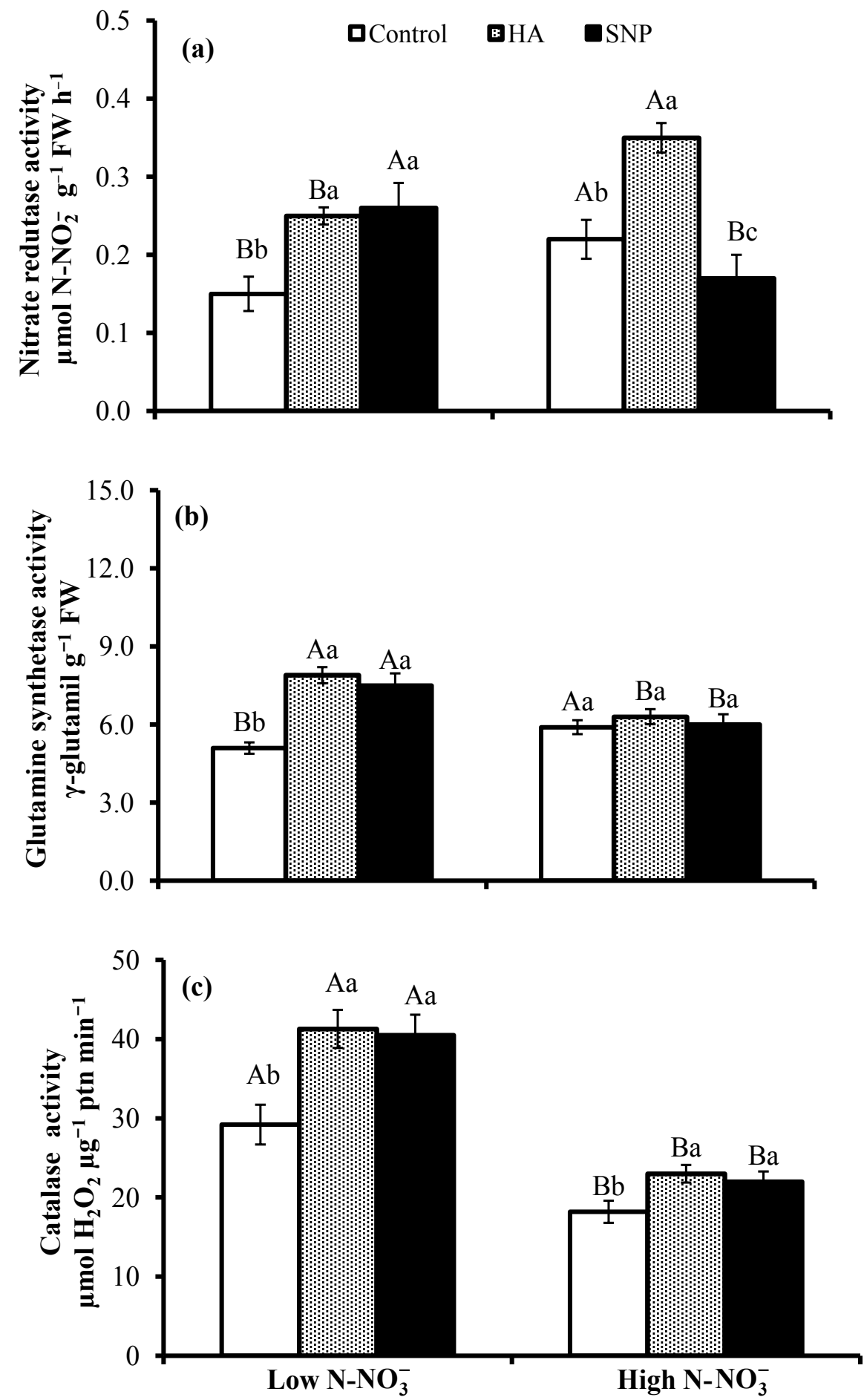

Figure 2. Activities of nitrate reductase (NR) (a), glutamine synthetase (GS) (b), and catalase (c) of basil hairy roots on the $5^{\text {th }}$ day of incubation in the Control (without HA or SNP); treatment with HA-humic acid extracted from haplichistosols (3 mM Carbon $\left.\mathrm{L}^{-1}\right)$; and treatment with SNP - sodium nitroprusside as an NO donor (100 $\left.\mu \mathrm{M} \mathrm{SNP}\right)$, applied in low $(0.5 \mathrm{mM})$ and high $(5.0 \mathrm{mM})$ doses of $\mathrm{N}^{-\mathrm{NO}_{3}^{-}}$. The same uppercase letter between the $\mathrm{N}-\mathrm{NO}_{3}^{-}$doses and the same lowercase letter within the $\mathrm{N}-\mathrm{NO}_{3}^{-}$doses do not differ among themselves according to the Scott-Knot test $(\mathrm{P} \leq 0.05)$. Vertical bars indicate standard error $(n=4)$. 
resulting from NR activity. Therefore, the application of high $\mathrm{N}-\mathrm{NO}_{3}^{-}$concentrations likely resulted in NO formation. The addition of exogenous NO, via the NO donor SNP, together with endogenous NO production, may have promoted $\mathrm{NO}$ accumulation, causing NR inhibition, which decreased the internal NO concentrations. With the lower $\mathrm{N}-\mathrm{NO}_{3}^{-}$supply, no significant differences in the NR activity were observed between the HA and SNP treatments.

Both the HA and SNP treatments resulted in increased root GS activity compared to the control, increasing it by approximately $40 \%$ (Figure 2(b)). Five days after the beginning of the experiment, GS activity was higher for the low than for the high $\mathrm{N}-\mathrm{NO}_{3}^{-}$supply.

Both the HA and SNP treatments resulted in increased catalase activity, especially with the lower $\mathrm{N}-\mathrm{NO}_{3}^{-}$supply (Figure $2(\mathrm{c})$ ). Two possible explanations exist for this result, both related to the limited amount of $\mathrm{N}$ in the culture medium $\left(0.5 \mathrm{mM} \mathrm{N}-\mathrm{NO}_{3}^{-}\right)$. The first is that the production of ROS, such as $\mathrm{H}_{2} \mathrm{O}_{2}$, is a stress signal in response to the low $\mathrm{N}^{-\mathrm{NO}_{3}^{-}}$levels in the culture medium. The second is that the $\mathrm{H}_{2} \mathrm{O}_{2}$ produced has an important physiological function, especially in the oxidative metabolism of the cell wall. This occurs because the ROS signaling activates enzymes that promote cell wall loosening, acting on plant cell growth. Catalase activity is therefore an indicator of root cell differentiation and growth processes.

The $\mathrm{NO}_{3}^{-}$concentrations were significantly higher for the HA and SNP treatments than for the control (Table 1) and were lower after 5 days of incubation,

Table 1. Nitrate $\left(\mathrm{N}-\mathrm{NO}_{3}^{-}\right)$, Ammonium $\left(\mathrm{N}-\mathrm{NH}_{4}^{+}\right)$, soluble sugar, and free amino-n content in hairy basil roots on the 5th day of incubation after application of treatments, for the Control (without HA or SNP); treatment with HA-humic acid extracted from haplichistosols (3 mM Carbon $\left.\mathrm{L}^{-1}\right)$; and treatment with $\mathrm{SNP}$-sodium nitroprusside, as an NO donor (100 $\mu \mathrm{M}$ SNP), applied in low $(0.5 \mathrm{mM})$ and high $(5.0 \mathrm{mM})$ doses of $\mathrm{N}-\mathrm{NO}_{3}^{-}$.

\begin{tabular}{|c|c|c|c|c|}
\hline & \multicolumn{2}{|c|}{$\mathrm{N}-\mathrm{NO}_{3}^{-}$} & \multicolumn{2}{|c|}{$\mathrm{N}-\mathrm{NH}_{4}^{+}$} \\
\hline & \multicolumn{4}{|c|}{$\mathrm{N}-\mathrm{NO}_{3}^{-}$in culture media } \\
\hline & Low & High & Low & High \\
\hline Control & $0.6 \mathrm{Bb}$ & $1.0 \mathrm{Ab}$ & $1.0 \mathrm{Ab}$ & $1.2 \mathrm{Ab}$ \\
\hline HA & $1.4 \mathrm{Aa}$ & $1.5 \mathrm{Aa}$ & $1.8 \mathrm{Aa}$ & $1.9 \mathrm{Aa}$ \\
\hline \multirow[t]{4}{*}{ SNP } & $1.3 \mathrm{Aa}$ & $1.3 \mathrm{Aa}$ & $1.7 \mathrm{Ba}$ & $2.0 \mathrm{Aa}$ \\
\hline & \multicolumn{2}{|c|}{ Soluble sugars } & \multicolumn{2}{|c|}{ Free amino-N } \\
\hline & \multicolumn{4}{|c|}{$\mathrm{N}-\mathrm{NO}_{3}^{-}$in culture media } \\
\hline & Low & High & Low & High \\
\hline Control & $17.2 \mathrm{Ba}$ & $23.1 \mathrm{Ab}$ & $6.5 \mathrm{Bb}$ & 7.6 Aa \\
\hline HA & $24.1 \mathrm{Ba}$ & $30.4 \mathrm{Aa}$ & $8.2 \mathrm{Aa}$ & $6.4 \mathrm{Bb}$ \\
\hline SNP & $22.1 \mathrm{Bb}$ & $28.7 \mathrm{Aa}$ & 8.0 Aa & $8.0 \mathrm{Aa}$ \\
\hline
\end{tabular}

The same uppercase letter between the $\mathrm{N}-\mathrm{NO}_{3}^{-}$doses and the same lowercase letter within the $\mathrm{N}_{-} \mathrm{NO}_{3}^{-}$ doses do not differ among themselves according to the Scott-Knot test $(\mathrm{P} \leq 0.05)$. 
showing higher $\mathrm{NO}_{3}^{-}$uptake in the first few days following $\mathrm{N}$ being supplied. No significant differences were observed between the HA and SNP treatments. Ammonium contents were higher for the HA and SNP treatments than for the control.

Soluble sugar levels are indicators of the intensity of the root metabolic activity. Soluble sugar concentrations were lower with the low than with high $\mathrm{N}-\mathrm{NO}_{3}^{-}$ supply (Table 1). Soluble sugar contents were higher for the HA and SNP treatments than for the control, showing that soluble sugars may provide energy for growth and nutrient uptake in transformed basil roots.

Free amino-N concentrations were higher for the HA and SNP treatments than for the control (Table 1). The $\mathrm{N}-\mathrm{NO}_{3}^{-}$supply increased the plant $\mathrm{N}$ contents in the plant, leading to increased free amino- $\mathrm{N}$ contents via the action of $\mathrm{N}$-assimilating enzymes. Even with low $\mathrm{N}-\mathrm{NO}_{3}^{-}$supply, the levels of amino- $\mathrm{N}$ did not decrease significantly, indicating that the plants were remobilizing the $\mathrm{NO}_{3}^{-}$accumulated in the vacuoles in order to maintain metabolic homeostasis. Aminoacids act as indirect regulators of NR activity, which may be related to their ability to change the $\mathrm{NO}_{3}^{-}$distribution in cellular pools, interfering with enzymatic activation [34]. The increase in aminoacid concentrations in the medium may have inhibited the NR activity in the high $\mathrm{NO}_{3}^{-}+\mathrm{SNP}$ treatment (Figure 2(a)).

Proton pumps in the transformed basil roots were positively modulated by the HA and SNP addition (Figure 3). The HA and SNP treatments had a positive effect on the activity of the plasma membrane P-type (Figure 3(a)) and V-type $\mathrm{H}^{+}$-ATPases (Figure 3(b)), with both $\mathrm{N}$ - $\mathrm{NO}_{3}^{-}$levels tested. Vacuolar $\mathrm{H}^{+}$-ATPase (V-type) activity was higher for the HA and SNP treatments with low than with high $\mathrm{NO}_{3}^{-}$supply (Figure $3(\mathrm{~b})$ ). This higher activity may be related to the $\mathrm{N}$ $\mathrm{NO}_{3}^{-}$storage (for later use) in cellular compartments such as vacuoles, due to the low $\mathrm{N}-\mathrm{NO}_{3}^{-}$concentration in the culture medium. The activity of proton pyrophosphatases $\left(\mathrm{H}^{+}\right.$-PPases) was also stimulated in treatments with the HA and SNP additions, with both $\mathrm{NO}_{3}^{-}$levels. The high $\mathrm{H}^{+}$-PPases activity after 5 days of incubation indicates that growth was more active during the first few days, with the formation of new tissue and continuous PPi production because $\mathrm{PPi}$ is an inexpensive energy source that can be used in vacuole acidification, acting on the control of vacuole membrane homeostasis. In addition, $\mathrm{H}^{+}$-PPases activity in cells undergoing growth helps conserve ATP, which is the energy currency of cells.

The effect of the tested treatments on in vivo NO histolocalization in the transformed basil roots is presented in Figure 4. Endogenous NO fluorescence was observed with both $\mathrm{N}-\mathrm{NO}_{3}^{-}$levels. Application of $\mathrm{HA}$ and SNP increased fluorescence emission, resulting in increases of approximately $250 \%$ and $150 \%$, respectively, with the lower $\mathrm{N}^{-\mathrm{NO}_{3}^{-}}$supply, and $200 \%$ and $100 \%$ with the higher $\mathrm{N}-\mathrm{NO}_{3}^{-}$supply compared to the control. Application of the $\mathrm{NO}$ scavenger (cPTIO) resulted in a $230 \%$ decrease in fluorescence emission for the HA treatment and a1 40\% decrease for the SNP treatment (a decrease of 180\% and 120\% 

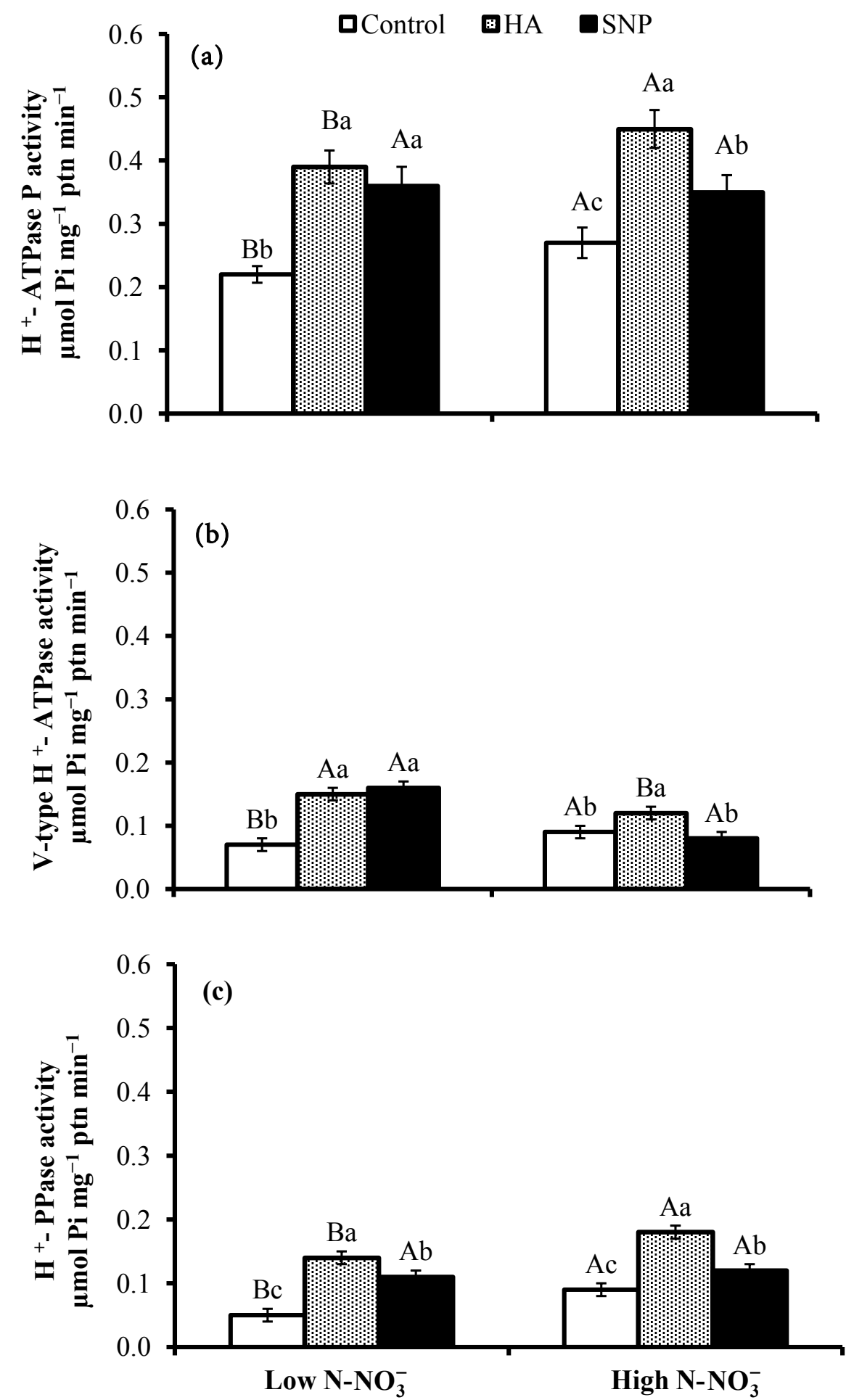

Figure 3. Activities of $\mathrm{H}^{+}$-ATPases $\mathrm{P}$ (a) and V-type (b) and $\mathrm{H}^{+}$-PPase (c) in basil hairy roots on the $5^{\text {th }}$ day of incubation in the Control (without HA or SNP); treatment with

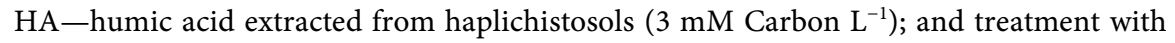
SNP_sodium nitroprusside, as an NO donor (100 $\mu \mathrm{M}$ SNP) applied in low $(0.5 \mathrm{mM})$ and high $(5.0 \mathrm{mM})$ doses of $\mathrm{N}-\mathrm{NO}_{3}^{-}$. The same uppercase letter between the $\mathrm{N}-\mathrm{NO}_{3}^{-}$dose and the same lowercase letter within the $\mathrm{N}^{-} \mathrm{NO}_{3}^{-}$dose do not differ among themselves according to the Scott-Knot test $(P \leq 0.05)$. Vertical bars indicate standard error $(n=4)$. 


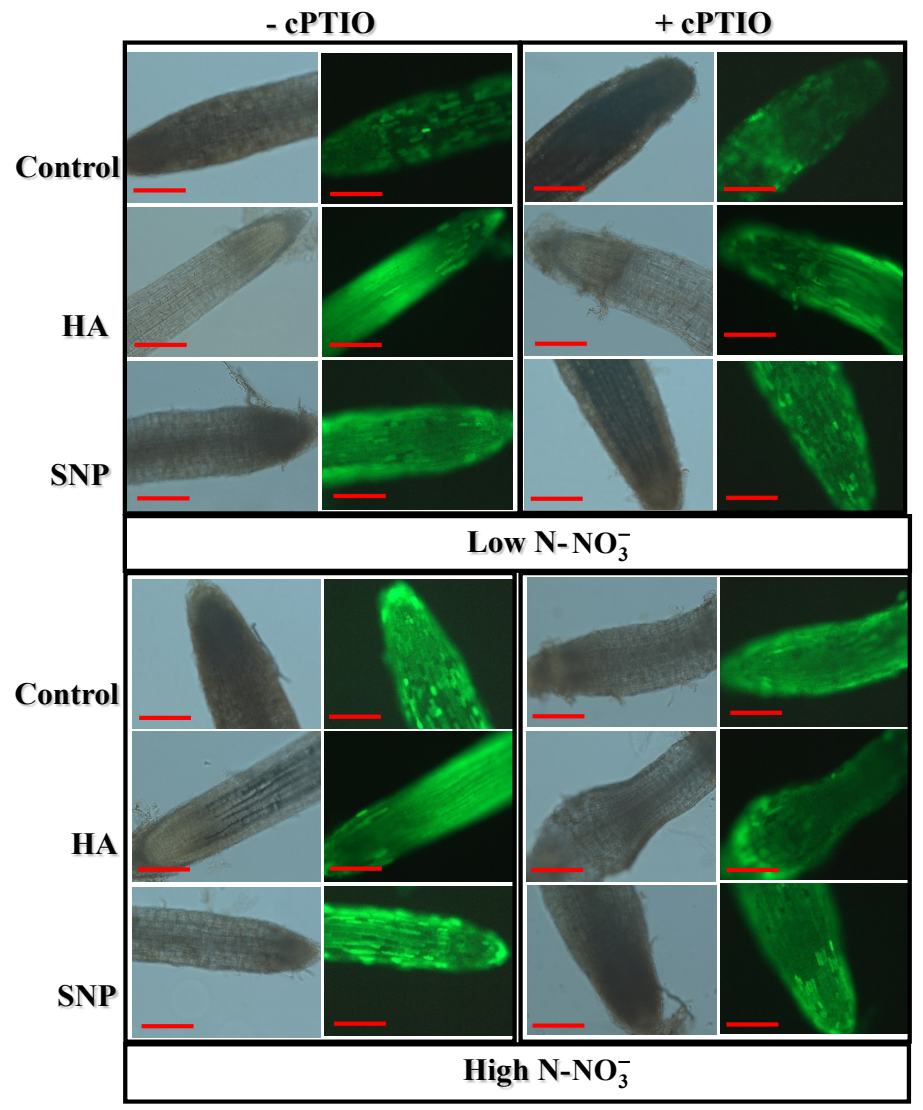

(a)

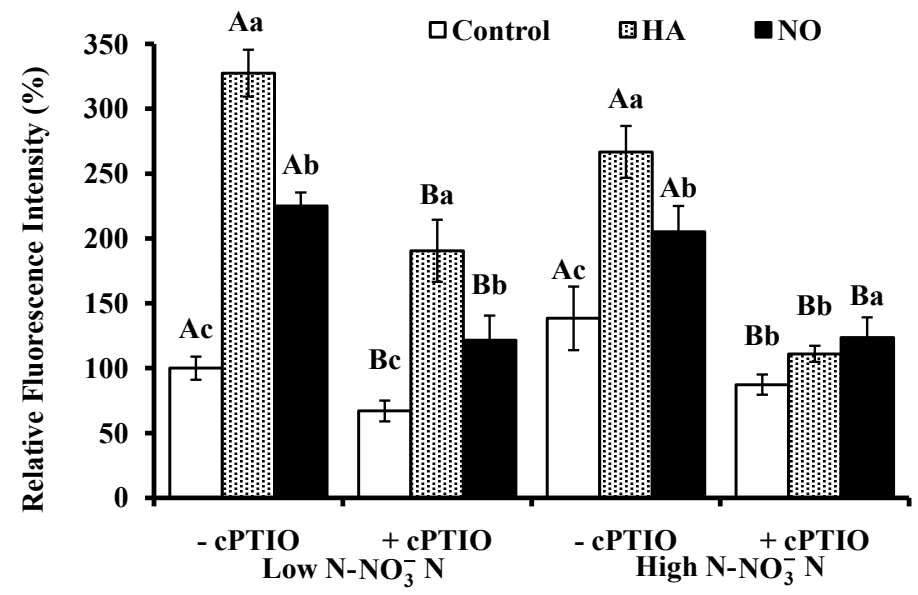

(b)

Figure 4. Effect of incubation with humic acid (HA), extracted from a haplic histosols (3 $\mathrm{mMC} \mathrm{L}^{-1}$ ), or with SNP (NO donor; $100 \mu \mathrm{M}$ SNP L ${ }^{-1}$ solution) on endogenous NO levels in root tips of hairy basil roots. Roots were grown with low $(0.5 \mathrm{mM})$ or high $\mathrm{N}-\mathrm{NO}_{3}^{-}$ supply $(5.0 \mathrm{mM}$ ) for 5 days, with or without cPTIO (NO scavenger). (a) Bright field and dark field microscopy images obtained using a fluorescence microscope and the fluorescent probe DAF-FM-DA, specific for NO. Bar $=200 \mu \mathrm{m}$ (red line in each figure). (b) Relative Fluorescence Intensity in root tips, expressed as relative number of pixels. In Figure $\mathrm{B}$, the same upper case letter between the presence and absence of cPTIO in the N- $\mathrm{NO}_{3}^{-}$ dose and the same lower case letter within the $\mathrm{N}-\mathrm{NO}_{3}^{-}$dose do not differ among themselves according to the Scott Knot test $(\mathrm{P} \leq 0.05)$. Vertical bars indicate standard error $(\mathrm{n}=6)$. 
compared to the HA and SNP treatments without cPTIO). With higher $\mathrm{N}-\mathrm{NO}_{3}^{-}$ supply, cPTIO sequestered NO more efficiently in the presence of HA and SNP compared to the control + cPTIO treatment, resulting in a $10 \%$ increase in fluorescence emission. With lower $\mathrm{N}-\mathrm{NO}_{3}^{-}$supply, the amount of cPTIO applied was not sufficient to sequester all the NO produced in hairy roots, resulting in an increase in fluorescence emission of $170 \%$ for the $\mathrm{HA}+\mathrm{cPTIO}$ treatment and $100 \%$ for the SNP + cPTIO treatment compared to the control.

Bright field microscopy showed differences in the root tip pattern. Dark-field light microscopy showed differences in the pattern of root tip development. Roots from the HA treatments were lighter and those from the SNP treatments were slightly lighter than roots from the control, under both the low and high $\mathrm{N}$ $\mathrm{NO}_{3}^{-}$supply (Figure 4(a)).

The effect of the HA and SNP treatments at low or high $\mathrm{N}^{-\mathrm{NO}_{3}^{-}}$supply on in vivo ROS histolocalization in the transformed basil roots is presented in Figure 5. The HA and SNP treatments resulted in significant increases in fluorescence emission, indicating increased ROS levels compared to the control, with both $\mathrm{N}$ $\mathrm{NO}_{3}^{-}$levels tested. The fluorescence response pattern was similar under both $\mathrm{N}$ $\mathrm{NO}_{3}^{-}$levels but was less pronounced with the higher than with the lower $\mathrm{N}$ $\mathrm{NO}_{3}^{-}$supply.

\section{Discussion}

A positive effect of both $\mathrm{HA}$ and SNP on the root growth of basil was observed in culture medium with different $\mathrm{N}-\mathrm{NO}_{3}^{-}$concentrations (Figure 1). HA possess bioactive molecules, auxin analogs, that may be weakly bound to the HS suprastructure and are released into the soil solution and made available for plant uptake by simple $\mathrm{pH}$ variations at the root interface, resulting from organic acidexudation [35]. HA and their hydrophobic domains may therefore act as a pool of chemical compounds that can promote the release of certain components, depending on the chemical signaling between plants and their growth environment. This interaction results in physicochemical changes to the external root environment, promoting structural changes to the HA suprastructural particles. These changes can apparently generate low-molecular-weight subunits/fragments such as auxins, which can potentially induce changes in plant cell metabolism. Auxins have been suggested to act on root development [6] and are present in soil organic matter [8]. Auxin signaling leads to pericycle cell division, with the formation of mitotic sites, which are lateral root precursors [36].

Root growth and development are highly responsive to nutrient availability [37] and inorganic $\mathrm{N}$ accessibility and input; $\mathrm{N}$ sources such as $\mathrm{NH}_{4}^{+}, \mathrm{NO}_{3}^{-}$, and NO should therefore be highlighted [38]. In the present study, induction of the root growth by $\mathrm{NO}_{3}^{-}$and $\mathrm{NO}$ was observed (Figure 1). In contrast to a previous report [39], the $\mathrm{HA}$ treatment with the low $\mathrm{N}-\mathrm{NO}_{3}^{-}$supply resulted in increased root size compared to the remaining treatments, indicating that this combination may activate a cascade of biochemical events culminating in root 


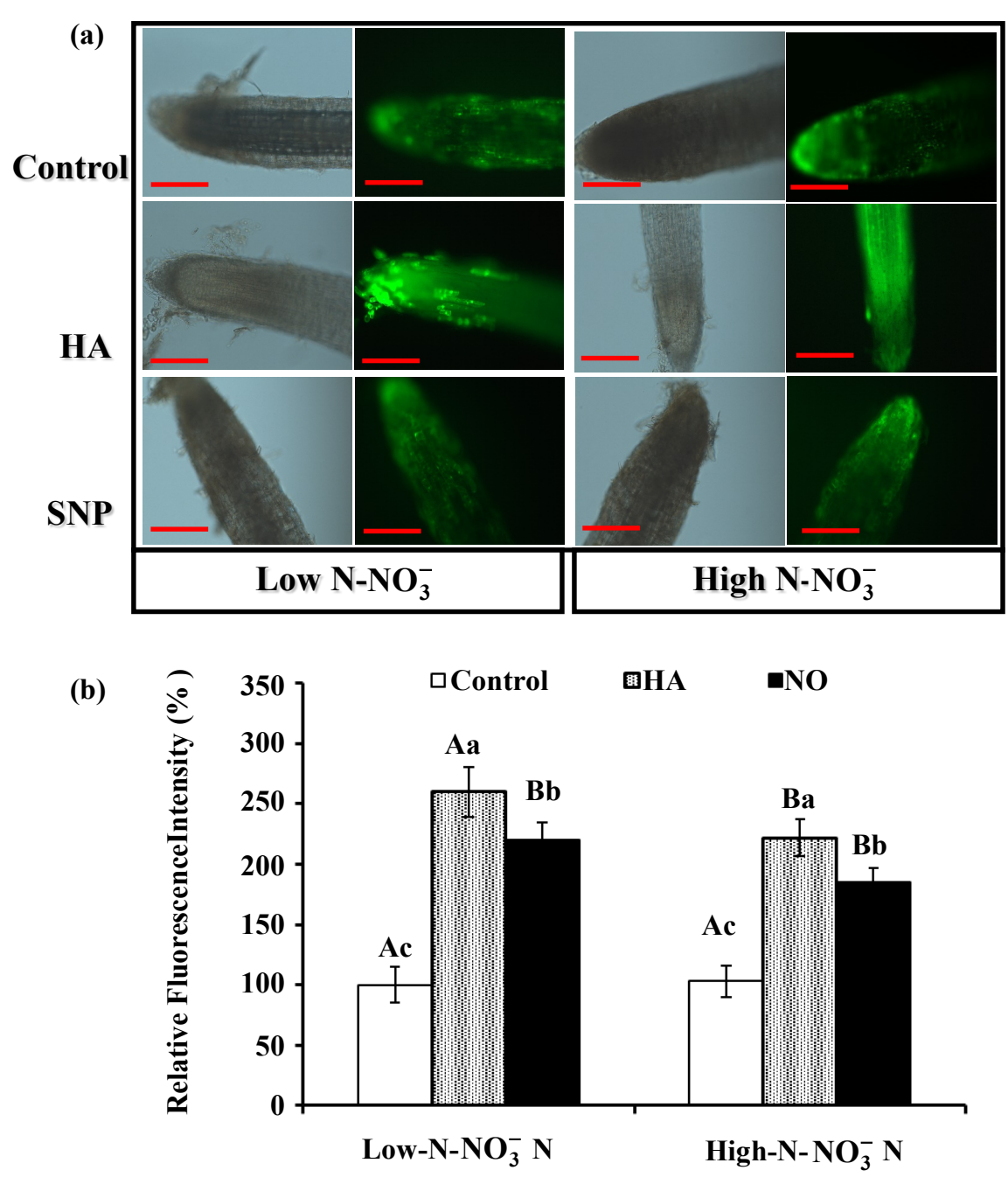

Figure 5. Effect of incubation with humic acid (HA), extracted from a haplic histosols (3

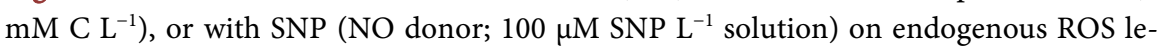
vels in the root tips of the hairy basil roots. Roots were grown with low $(0.5 \mathrm{mM})$ or high $\mathrm{N}-\mathrm{NO}_{3}^{-}$supply $(5.0 \mathrm{mM}$ ) for 5 days, with or without cPTIO (NO scavenger). (a) Bright field and dark field microscopy images obtained using a fluorescence microscope and the fluorescent probe $\mathrm{H}_{2}$ DCFDA, specific for $\mathrm{H}_{2} \mathrm{O}_{2}$. Bar $=200 \mu \mathrm{m}$. (b) Relative Fluorescence Intensity in the root tips, expressed as the relative number of pixels. In (b), the same upper case letter indicates no significant differences between different $\mathrm{N}-\mathrm{NO}_{3}^{-}$levels, and lower case letters within the same $\mathrm{N}-\mathrm{NO}_{3}^{-}$supply, according to the Scott Knot test $(\mathrm{P} \leq$ $0.05)$. Vertical bars indicate standard errors $(n=6)$.

growth promotion. Similar behavior was observed for the NO treatment. The $\mathrm{NO}_{3}^{-}$signaling pathways, which stimulate lateral root (LR) elongation under mild $\mathrm{N}$ deficiency, involve the gene expression of key transporters and enzymes [40]. In a study of expression of specific genes by RNA-Seq, nitrate was observed to trigger lateral root initiation in corn roots through auxin regulation of the cell cycle [40] [41].

The $\mathrm{NO}_{3}^{-}$signaling dynamics on soil-plant systems were discussed by [12], who reported evidence of external $\mathrm{NO}_{3}^{-}$sensing by roots, modulating the ex- 
pression of key proteins involved in $\mathrm{N}$ metabolism, such as NR. NR is a very important enzyme because it is responsible for a key step in the $\mathrm{N}$ assimilation pathway, converting $\mathrm{NO}_{3}^{-}$into $\mathrm{NO}_{2}^{-}$[42]. In addition, $\mathrm{NR}$ is considered the main NO source under conditions of high $\mathrm{NO}_{3}^{-}$influx into the roots [13], leading to increased $\mathrm{NO}_{3}^{-}$concentrations in cells, where it is quickly converted into nitrite, which accumulates, shifting the reaction equilibrium towards NO production. In the present study, the HA treatment had a positive effect on NR activity (Figure 2(a)). SNP addition resulted in similar responses to the HA treatments, except for the lower $\mathrm{NR}$ activity with the higher $\mathrm{N}-\mathrm{NO}_{3}^{-}$supply observed with SNP addition. This finding indicates a regulatory role of NO on NR activity, which depended on the $\mathrm{N}-\mathrm{NO}_{3}^{-}$level in the culture medium.

Taken together, the soluble fraction concentrations and the NR and GS activity results were expressed 5 days after the beginning of the experiment. This may have been due to higher initial stimulation by the HA and SNP. GS is a limiting enzyme for plant growth and $\mathrm{N}$ use [43] because it is one of the key enzymes responsible for $\mathrm{N}-\mathrm{NH}_{4}^{+}$assimilation. In the present study, high GS activity was observed on both evaluations (Figure 2(b)). This may have been related to changes in the cell metabolism triggered by $\mathrm{NO}_{3}^{-}$signaling [39].

In the present study, the HA and SNP treatments were observed to affect the evaluated parameters, under both $\mathrm{N}-\mathrm{NO}_{3}^{-}$levels tested, with a positive effect on $\mathrm{N}$ metabolism. This was evaluated by determining the $\mathrm{N}-\mathrm{NO}_{3}^{-}, \mathrm{N}-\mathrm{NH}_{4}^{+}$, and free amino- $\mathrm{N}$ concentrations (Table 1$)$ and the proton pump activity $\left(\mathrm{P}-\mathrm{H}^{+}-\right.$ ATPases, $\mathrm{V}-\mathrm{H}^{+}$-ATPases, and $\mathrm{H}^{+}$-PPases; Figure 3 ), in the transformed basil roots.

$\mathrm{N}-\mathrm{NO}_{3}^{-}$influx is an active process that depends on the proton gradients generated by $\mathrm{H}^{+}$-ATPases and is catalyzed by a combination of a high-affinity (HATS) and a low affinity transport system (LATS). Cells may invest approximately $50 \%$ of their energy reserves on maintaining the ion gradients across the cell membranes [44]. Decreases in the $\mathrm{N}-\mathrm{NO}_{3}^{-}$levels may therefore result in decreased energy consumption, resulting in the accumulation of soluble sugars, which was observed after 5 days of incubation (Table 1 ). The HATS is activated when the external $\mathrm{NO}_{3}^{-}$concentrations are under $0.5 \mathrm{mM}$, and they are negative-feedback regulated by $\mathrm{NO}_{3}^{-}$assimilation products. A pronounced decrease in $\mathrm{NO}_{3}^{-}$under these conditions may therefore result in low $\mathrm{NO}_{3}^{-}$uptake efficiency at low $\mathrm{NO}_{3}^{-}$concentrations.

The present results indicate that part of the $\mathrm{N}-\mathrm{NO}_{3}^{-}$taken was reduced into $\mathrm{N}-\mathrm{NH}_{4}^{+}$, and the excess $\mathrm{N}-\mathrm{NO}_{3}^{-}$was stored in vacuoles. $\mathrm{NR}$ activity reflects the circulation of $\mathrm{N}-\mathrm{NO}_{3}^{-}$in the cytosol, which was not affected by the $\mathrm{N}-\mathrm{NO}_{3}^{-}$ accumulated in the vacuoles [45]. Therefore, independently of the $\mathrm{N}-\mathrm{NO}_{3}^{-}$ concentrations in the medium, $\mathrm{N}-\mathrm{NO}_{3}^{-}$concentrations in the cytosol were similar under both $\mathrm{N}-\mathrm{NO}_{3}^{-}$levels tested, and the excess $\mathrm{N}-\mathrm{NO}_{3}^{-}$taken was stored in vacuoles (Table 1), depending on proton gradient generation by $\mathrm{H}^{+}$-ATPases.

In the present study, high $\mathrm{N}-\mathrm{NH}_{4}^{+}$concentrations and GS activity were ob- 
served in the tissues of transformed basil roots (Table 1), indicating that during the first few days of incubation, a high demand of $\mathrm{N}-\mathrm{NH}_{4}^{+}$for incorporation into aminoacids and synthesis of the necessary protein for biosynthesis was observed. $\mathrm{N}-\mathrm{NH}_{4}^{+}$is used for synthesis of glutamine and glutamate, which serve as nitrogen donors for biosynthesis. $\mathrm{N}-\mathrm{NH}_{4}^{+}$assimilation may occur via two pathways. The main pathway involves two enzymes GS and glutamate synthase (GOGAT) and the second the enzyme glutamate dehydrogenase (GDH). High free amino- $\mathrm{N}$ concentrations (Table 1) may have also contributed to the $\mathrm{N}$ $\mathrm{NO}_{3}^{-}$accumulation in root tissues, since studies have shown that $\mathrm{NO}_{3}^{-}$and its reduction products affect $\mathrm{N}-\mathrm{NO}_{3}^{-}$uptake and reduction.

In the present study, $\mathrm{HA}$ and SNP application significantly increased plasma membrane (PM) ATPase activity compared to the controls under both $\mathrm{N}-\mathrm{NO}_{3}^{-}$ levels tested. Similar behavior was observed for the roots treated with HA or SNP, suggesting that the HA action mechanism depends on auxin signaling pathways. Growth induction and mitotic site promotion (Figure 1(a) and Figure 1 (b), respectively) seem to be related to proton pump activation (Figure 3), stimulated by the endogenous NO production induced by HA (Figure 4 and Figure 5). Studies have shown that the over expression of $\mathrm{H}^{+}$-PPase sincreasesapoplastic acidification, increasing the $\mathrm{H}^{+}$-ATPase activity at the plasma membrane and resulting in higher auxin transport, related to an increased number of root primordia and cell differentiation [46]. In the present study, the application of HA and SNP increased the $\mathrm{H}^{+}$-PPase activity, in agreement with [5].

Considering what was discussed above, and accepting the role of NO on root growth promotion [11] [12] [13], the present results indicate that HA addition promoted an increase in NO levels. This process was analyzed by fluorescence microscopy (Figure 4 and Figure 5), and similar responses to those previously observed for the addition of auxin were found [14]. This result agrees with [5], who observed increased NO levels in corn roots in response to the HA addition.

HA and SNP application caused increases in root growth, and partially reverted the root growth inhibition caused by the higher $\mathrm{N}^{-\mathrm{NO}_{3}^{-}}$supply. This finding indicates that endogenous $\mathrm{NO}$ levels (Figure 4) may decrease when roots are grown under high $\mathrm{N}-\mathrm{NO}_{3}^{-}$concentrations (Table 1) and that the application of HA and SNP may reverse this response. These results indicate that root lignification was higher for the control and SNP treatments than for the HA treatment, since HA presents auxinic activity and could act on root cell elongation. Treatments with the NO scavenger PTIO showed a different root tip pattern, forming cell clusters, suggesting that cells were prevented from growing, and showing darker color (Figure 4(a)). Based on the discussed results, NO was involved in the root growth, activating enzymes such as proton pumps and promoting the $\mathrm{N}-\mathrm{NO}_{3}^{-}$uptake induced by $\mathrm{HA}$.

ROS are considered part of the plant oxidative burst under detrimental conditions [7]. However, recent evidence has shown that they play specific roles in plant growth regulation and cell signaling [7] [47]. The HA and SNP treatments 
increased ROS emission (Figure 5). [47] proposed that the ROS $\mathrm{H}_{2} \mathrm{O}_{2}$ could react to form hydroxylradicals in the apoplast and be responsible for polysaccharide cleavage, resulting in cell wall loosening. ROS accumulation is known to be required for root growth, functioning as secondary messengers in hormone signaling. Studies have indicated that ROS are sensitive to the $\mathrm{N}$ supply, especially $\mathrm{H}_{2} \mathrm{O}_{2}$, which is involved in the root growth that depends on the $\mathrm{N}-\mathrm{NO}_{3}^{-}$levels [10]. The $\mathrm{H}_{2} \mathrm{O}_{2}$ produced in cells plays an important physiological role, especially on cell wall oxidative metabolism, because it signals the activity of enzymes that promote cell wall loosening, such as cellulases, hemicellulases, glucanases, and pectinases, acting on plant cell growth [48]. Regarding the effect of $\mathrm{H}_{2} \mathrm{O}_{2}$ accumulation, studies have shown that catalase activity may be correlated with the $\mathrm{H}_{2} \mathrm{O}_{2}$ levels inside cells, since it catalyzes the dismutation of $\mathrm{H}_{2} \mathrm{O}_{2}$ to $\mathrm{O}_{2}$ and $\mathrm{H}_{2} \mathrm{O}$. Catalase activity therefore indicates root cell differentiation and growth. In the present study, high catalase activity was observed (Figure 2(c)), being more significant with low $\mathrm{N}-\mathrm{NO}_{3}^{-}$.

[49] evaluated the effect of the $\mathrm{NO}_{3}^{-}$supply on corn root growth and observed decreased $\mathrm{H}_{2} \mathrm{O}_{2}$ levels with increasing $\mathrm{NO}_{3}^{-}$levels and significantly lower root growth with decreased $\mathrm{H}_{2} \mathrm{O}_{2}$, indicating that ROS are needed for root growth promotion and that the $\mathrm{NO}_{3}^{-}$supply affects this process. The HA and SNP treatments increased ROS emission (Figure 5). This increase may have stimulated the expression of catalase, resulting in increased catalase activity to decrease the oxidative effects of the ROS. The observed significant correlation ( $\mathrm{r}$ $=+0.91$ ) between the catalase activity and ROS fluorescence emission supports the hypothesis that the catalase was acting to decrease the ROS oxidative effects during root growth.

Root growth (Figure 1), together with the ROS production observed for the HA and SNP treatments (Figure 5), indicate an essential role of ROS in promoting root growth, since they are responsible for polysaccharide cleavage, resulting in cell wall loosening and enlargement. The cell wall is a dynamic anatomical structure, with an important role on cell growth regulation [50]. Metabolism of ROS plays a decisive role in cell differentiation and development. Therefore, the $\mathrm{H}_{2} \mathrm{O}_{2}$ resulting from oxidative unbalance may act as a secondary messenger, inducing the expression of some genes responsible for the induction of morphogenetic processes. Considering the present results, it is proposed that the mechanism of HA action on root growth is mediated by NO and ROS production, which may act as secondary messengers, activating the genes responsible for cell growth.

\section{Conclusion}

HA resulted in a significant increase in root growth in basil, in association with increased NO and ROS contents. NO acted on the activation of enzymes such as the proton pumps and promoted $\mathrm{N}-\mathrm{NO}_{3}^{-}$uptake. HA had a positive effect on $\mathrm{NR}$ activity, which was regulated by $\mathrm{NO}$ and the $\mathrm{N}-\mathrm{NO}_{3}^{-}$level in the culture 
medium. HA and SNP increased the soluble sugar contents and $\mathrm{N}$ metabolism, as indicated by the soluble fractions $\left(\mathrm{N}-\mathrm{NO}_{3}^{-}, \mathrm{N}-\mathrm{NH}_{4}^{+}\right.$, and free amino- $\mathrm{N}$ contents). High $\mathrm{N}-\mathrm{NH}_{4}^{+}$contents and GS activity were observed in the transformed basil roots. In contrast to reports for other species, root growth increased with low $\mathrm{N}-\mathrm{NO}_{3}^{-}$supply and $\mathrm{HA}$ application. Further studies focusing on the gene expression of key proteins responsive to $\mathrm{HA}$, NO, and ROS signaling in Ocimum basilicum L. would be of interest.

\section{Acknowledgements}

The authors would like to acknowledge the CNPq and FAPERJ. Technical support was provided by the Programa de Pós-Graduação em Agronomia-Ciência do Solo (CPGA-CS) and the Graduate Program in Chemistry (PPGQ) at Federal Rural University of Rio de Janeiro (UFRRJ).

\section{References}

[1] Koevoets, I.T., Venema, J.H., Elzenga, J.T.M. and Testerink, C. (2016) Roots Withstanding Their Environment: Exploiting Root System Architecture Responses to Abiotic Stress to Improve Crop Tolerance. Frontiers in Plant Science, 7, 1-19. https://doi.org/10.3389/fpls.2016.01335

[2] Zhong, Y., Yan, W., Chen, J. and Shangguan, Z. (2014) Net Ammonium and Nitrate Fluxes in Wheat Roots under Different Environmental Conditions as Assessed by Scanning Ion-Selective Electrode Technique. Scientific Reports, 4, 1-9.

[3] Gruber, B.D., Giehl, R.F.H., Friedel, S. and Von Wiren, N. (2013) Plasticity of the Arabidopsis Root System under Nutrient Deficiencies. Plant Physiology, 163, 161-179. https://doi.org/10.1104/pp.113.218453

[4] Orsel, M. and Miller, A.J. (2010) Transport Systems for $\mathrm{NO}_{3}{ }^{-}$and $\mathrm{NH}_{4}{ }^{+}$. In: Foyer, C.H. and Zhang, H., Eds., Annual Plant Reviews Volume 42: Nitrogen Metabolism in Plants in the Post-Genomic Era, Wiley-Blackwell, Oxford, 1-366. https://doi.org/10.1002/9781444328608.ch4

[5] Zandonadi, D.B., Santos, M.P., Dobbss, L.B., Olivares, F.L., Canellas, L.P., Binzel, M.L., et al. (2010) Nitric Oxide Mediates Humic Acids-Induced Root Development and Plasma Membrane $\mathrm{H}^{+}$-ATPase Activation. Planta, 231, 1025-1036. https://doi.org/10.1007/s00425-010-1106-0

[6] Saini, S., Sharma, I., Kaur, N. and Pati, P.K. (2013) Auxin: A Master Regulator in Plant Root Development. Plant Cell Reports, 32, 741-757.

https://doi.org/10.1007/s00299-013-1430-5

[7] García, A.C., Olaetxea, M., Santos, L.A., Mora, V., Baigorri, R., Fuentes, M., Zamarreño, A.M., et al. (2016) Involvement of Hormone- and ROS-Signaling Pathways in the Beneficial Action of Humic Substances on Plants Growing under Normal and Stressing Conditions. BioMed Research International, 2016, 1-13. https://doi.org/10.1155/2016/3747501

[8] Canellas, L.P. and Olivares, F.L. (2014) Physiological Responses to Humic Substances as Plant Growth Promoter. Chemical and Biological Technologies in Agriculture, 1, 3. http://www.chembioagro.com/content/1/1/3

[9] Mora, V., Bacaicoa, E., Zamarreño, A.M., Aguirre, E., Garnica, M., et al. (2010) Action of Humic Acid on Promotion of Cucumber Shoot Growth Involves Nitrate-Related Changes Associated with the Root-to-Shoot Distribution of Cytoki- 
nins, Polyamines and Mineral Nutrients. Journal of Plant Physiology, 167, 633-642.

[10] Cordeiro, F.C., Santa-Catarina, C., Silveira, V. and Souza, S.R. (2011) Humic Acid Effect on Catalase Activity and the Generation of Reactive Oxygen Species in Corn (Zea mays). Bioscience, Biotechnology, and Biochemistry, 75, 70-74. https://doi.org/10.1271/bbb.100553

[11] Trevisan, S., Manoli, A. and Quaggiotti, S. (2014) NO Signaling Is a Key Component of the Root Growth Response to Nitrate in Zea mays L. Plant Signaling \& Behavior, 9, 28274.

[12] Manoli, A., Begheldo, M., Genre, A., Lanfranco, L., Trevisan, S. and Quaggiotti, S. (2014) NO Homeostasis Is a Key Regulator of Early Nitrate Perception and Root Elongation in Maize. Journal of Experimental Botany, 65, 185-200. https://doi.org/10.1093/jxb/ert358

[13] Sun, H., Li, J., Song, W., Tao, J., Huang, S., Chen, S., Hou, M., Xu, G. and Zhang, Y. (2015) Nitric Oxide Generated by Nitrate Reductase Increases Nitrogen Uptake Capacity by Inducing Lateral Root Formation and Inorganic Nitrogen Uptake under Partial Nitrate Nutrition in Rice. Journal of Experimental Botany, 66, 2449-2459. https://doi.org/10.1093/jxb/erv030

[14] Pagnussat, G.C., Simontacchi, M., Puntarulo, S. and Lamattina, L. (2002) Nitric Oxide Is Required for Root Organogenesis. Plant Physiology, 129, 954-956. https://doi.org/10.1104/pp.004036

[15] Mittler, R., Vanderauwera, S., Suzuki, N., et al. (2011) ROS Signaling: The New Wave? Trends in Plant Science, 16, 300-309.

[16] Tripathy, B.C. and Oelmüller, R. (2012) Reactive Oxygen Species Generation and Signaling in Plants. Plant Signaling \& Behavior, 7, 1621-1633. https://doi.org/10.4161/psb.22455

[17] Swanson, S. and Gilroy, S. (2010) ROS in Plant Development. Physiologia Plantarum, 138, 84-92. https://doi.org/10.1111/j.1399-3054.2009.01313.x

[18] Mora, V., Baigorri, R., Bacaico, E., Zamarreno, A.M. and García-mina, J.M. (2012) The Humic Acid-Induced Changes in the Root Concentration of Nitric Oxide, IAA and Ethylene Do Not Explain the Changes in Root Architecture Caused by Humic Acid in Cucumber. Environmental and Experimental Botany, 76, 24-32.

[19] Mora, V., Olaetxea, M., Bacaicoa, E., Baigorri, R., Fuentes, M., Zamarreño, A.M. and Garcia-Mina, J.M. (2014) Abiotic Stress Tolerance in Plants: Exploring the Role of Nitric Oxide and Humic Substances. In: Nasir Khan, M., Mobin, M., Mohammad, F. and Corpas, F.J., Eds., Nitric Oxide in Plants. Metabolism and Role in Stress Physiology, Springer, Amsterdam, 243-264. https://doi.org/10.1007/978-3-319-06710-0_15

[20] Chhetri, B.K., Ali, N.A. and Setzer, W.N. (2015) A Survey of Chemical Compositions and Biological Activities of Yemeni Aromatic Medicinal Plants. Medicines, 2, 67-92. https://doi.org/10.3390/medicines2020067

[21] Nicomedes Júnior, J., Ribeiro, C.R., Berbara, R.L.L., Stark, E.M.L.M., Otoni, W.C.O. and Souza, S.R. (2017) Produção de raízes transgênicas de Ocimum basilicum: técnicas de transformação e linhagens de Agrobacterium rhizogenes. Nativa.

[22] Schnitzer, M. and Skinner, L. (1982) Organic Matter Characterization. In: American Society of Agronomy/Soil Science Society of America, Eds., Method of Soil Analysis, Part 2, Chemical and Mineralogical Properties, Agronomic Monograph, ASA/SSSA Publishers, Madison, 581.

[23] Cataldo, D., Marron, M., Schrader, L.E. and Youngs, V.L. (1975) Rapid Colorime- 
tric Determination of Nitrate in Plant Tissue by Nitration of Salicylic Acid. Communication in Soil Science and Plant Analysis, 6, 853-855. https://doi.org/10.1080/00103627509366547

[24] Yemm, E.W. and Cocking, E.C. (1955) The Determination of Animo-Acid with Ninhydrin. Analytical Biochemistry, 80, 209-213.

[25] Felker, P. (1977) Microdetermination of Nitrogen in Seed Protein Extracts. Analytical Chemistry, 49, 1980. https://doi.org/10.1021/ac50015a053

[26] Yemm, E.W. and Willis, A.J. (1954) The Estimation of Carbohydrate in Plants Extracts by Anthrone. Biochemistry, 57, 508-514. https://doi.org/10.1042/bj0570508

[27] Jaworski, E.G. (1971) Nitrate Reductase Assay in Intact Plant Tissues. Biochemical and Biophysical Research Communications, 43, 1274-1279.

[28] Farnden, K.J.S. and Robertson, J.G. (1980) Methods for Studying Enzyme Envolved in Metabolism Related to Nitrogen. In: Bergsen, F.J., Ed. Methods for Evaluating Biological Nitrogen Fixation, Chichester, 65-314.

[29] Azevedo, R.A., Alas, R.M., Smith, R.J. and Lea, P.J. (1998) Response of Antioxidant Enzymes to Transfer from Elevated Carbon Dioxide to Air and Ozone Fumigation, in the Leaves and Roots of Wild-Type and a Catalase-Deficient Mutant of Barley. Physiologia Plantarum, 104, 280-292. https://doi.org/10.1034/j.1399-3054.1998.1040217.x

[30] Anderson, J.V. and Davis, D.G. (2004) Abiotic Stress Alters Transcript Profiles and Activity of Glutathione S-Transferase, Glutathione Peroxidase, and Glutathione Reductase in Euphorbia esula. Physiologia Plantarum, 120, 421-433. https://doi.org/10.1111/j.0031-9317.2004.00249.x

[31] Yan, F., Zhu, Y., Muller, C., Zorb, C. and Schubert, S. (2002) Adaptation of $\mathrm{H}^{+}$-Pumping and Plasma Membrane $\mathrm{H}^{+}$ATPase Activity in Proteoid Roots of White Lupin under Phosphate Deficiency. Plant Physiology, 129, 50-63. https://doi.org/10.1104/pp.010869

[32] Bradford, M.M. (1976) Rapid and Sensitive Method for Quantification of Microgram Quantities of Protein Utilizing the Principle of Protein Dye-Binding. Analytical Biochemistry, 72, 248-254.

[33] Laxalt, A.M., Raho, N., Have, A.T. and Lamattina, L. (2007) Nitric Oxide Is Critical for Inducing Phosphatidic Acid Accumulation in Xylanase-Elicited Tomato Cells. The Journal of Biological Chemistry, 282, 21160-21168. https://doi.org/10.1074/jbc.M701212200

[34] Lea, P.J. and Azevedo, R.A. (2006) Nitrogen Use Efficiency. 1. Uptake of Nitrogen from the Soil. Annals of Applied Biology, 149, 243-247. https://doi.org/10.1111/j.1744-7348.2006.00101.x

[35] Dobbss, L.B., Canellas, L.P., Olivares, F.L., Aguiar, N.O., Peres, L.E.P., et al. (2010) Bioactivity of Chemically Transformed Humic Matter from Vermicompost on Plant Root Growth. Journal of Agricultural and Food Chemistry, 58, 3681-3688. https://doi.org/10.1021/jf904385c

[36] Overvoorde, P., Fukaki, H. and Beeckman, T. (2010) Auxin Control of Root Development. Cold Spring Harbor Perspectives in Biology, 62, 1455-1466.

[37] Kraiser, T., Gras, D.E., Gutiérrez, A.G., González, B. and Gutiérrez, R.A. (2011) A Holistic View of Nitrogen Acquisition in Plants. Journal of Experimental Botany, 62, 1455-1466. https://doi.org/10.1093/jxb/erq425

[38] Giehl, R.F.H., Lima, J.E. and Von Wirén, N. (2012) Regulatory Components Involved in Altering Lateral Root Development in Response to Localized Iron: Evi- 
dence for Natural Genetic Variation. Plant Signaling \& Behavior, 7, 711-713. https://doi.org/10.4161/psb.20337

[39] Mounier, E., Pervent, M., Ljung, K., Gojon, A. and Nacry, P. (2014) Auxin-Mediated Nitrate Signalling by NRT1.1 Participates in the Adaptive Response of Arabidopsis Root Architecture to the Spatial Heterogeneity of Nitrate Availability. Plant, Cell and Environment, 37, 162-174. https://doi.org/10.1111/pce.12143

[40] Sun, C.H., Yu, J.Q. and Hu, D.G. (2017) Nitrate: A Crucial Signal during Lateral Roots Development. Frontiers in Plant Science, 8, 485. https://doi.org/10.3389/fpls.2017.00485

[41] Yu, P., Li, X., Yuan, L. and Li, C. (2014) A Novel Morphological Response of Maize (Zea mays) Adult Roots to Heterogeneous Nitrate Supply Revealed by a Split-Root Experiment. Physiologia Plantarum, 150, 133-144.

[42] Truong, H.N. and Meyer, C. (2016) A New NO Ledge in Chlamydomonas: When the Old Nitrate Reductase Meets Amidoxime Reducing Component to Produce Nitric Oxide. Plant, Cell and Environment, 39, 2095-2096.

https://doi.org/10.1111/pce.12803

[43] Zhang, Z., Xiong, S., Wei, Y., Meng, M., Wang, X. and Ma, X. (2017) The Role of Glutamine Synthetase Isozymes in Enhancing Nitrogen Use Efficiency of N-Efficient Winter Wheat. Scientific Reports, 7, 1-12. https://doi.org/10.1038/s41598-017-01071-1

[44] Nelson, N. (1994) Energizing Porters by Proton-Motive Force. Journal of Experimental Biology, 196, 7-13.

[45] Han, Y.L., Song, H.X., Liao, Q., Yu, Y., Jian, S.F., Lepo, J.E., Liu, Q., et al. (2016) Nitrogen Use Efficiency Is Mediated by Vacuolar Nitrate Sequestration Capacity in Roots of Brassica napus. Plant Physiology, 170, 684-1698.

[46] Fan, W., Wang, H., Wu, Y., Yang, N., Yang, J. and Zhang, P. (2017) $\mathrm{H}^{+}$-Pyrophosphatase IbVP1 Promotes Efficient iron Use in Sweet Potato [Ipomoeabatatas (L.) Lam.]. Plant Biotechnology Journal, 15, 698-712. https://doi.org/10.1111/pbi.12667

[47] Schmidt, R., Kunkowska, A.B. and Schippers, J.H.M. (2016) Role of Reactive Oxygen Species during Cell Expansion in Leaves. Plant Physiology, 172, 2098-2106. https://doi.org/10.1104/pp.16.00426

[48] Lu, D., Wang, T., Persson, S., Mueller-Roeber, B. and Schippers, J.H.M. (2014) Transcriptional Control of ROS Homeostasis by KUODA1 Regulates Cell Expansion during Leaf Development. Nature Communications, 5, 1-9. https://doi.org/10.1038/ncomms4767

[49] Zhao, D.Y., Tian, Q.Y., Li, L.H. and Zhang, W.H. (2007) Nitric Oxide Is Involved in Nitrate-Induced Inhibition of Root Elongation in Zea mays. Annals of Botany, 100, 497-503. https://doi.org/10.1093/aob/mcm142

[50] Potters, G., Pasternak, T., Guisez, Y., Palme, K.J. and Jansen, M. (2007) Strees-Induced Morphogenic Responses: Growing Out of Trouble? Trends in Plant Science, 12, 98-105. 